\title{
CineMA, MÚSICA E TRADUÇão: PEDRO AlMODÓVAR LEGENDADO EM PORTUGAL
}

\author{
CiNEMA, MUSIC AND TRANSLATION: PEDRO ALMODÓVAR SUBTITLED \\ IN PORTUGAL
}

\section{CINE, MÚSICA Y TRADUCCIÓN: PEDRO ALMODÓVAR SUBTITULADO EN PORTUGAL}

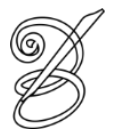 \\ M. Dolores Lerma SANCHIS* \\ Universidade do Minho, Portugal
}

\begin{abstract}
Resumo: Desde o nascimento do cinema, a música faz parte dos filmes. Na obra de Pedro Almodóvar, a trilha sonora ocupa um lugar central, falando das personagens e participando nas narrativas. O objetivo final desta pesquisa é constatar (ou não) a existência de tendências ou normas de tradução no caso específico das músicas que integram os filmes, seguindo a distinção estabelecida por Toury (1985) entre normas preliminares e normas operacionais. Partimos do estudo de um corpus composto pelas últimas oito longas-metragens do realizador espanhol - desde Todo sobre mi madre (1999), que obteve o Óscar para o melhor filme em língua estrangeira, até ao último filme estreado em Portugal, Julieta (2016). Consideramos que aspetos como a intercompreensão e a proximidade linguística e territorial poderão influenciar as soluções adotadas pelos tradutores nas legendagens. A pesquisa nos permite concluir que não existe homogeneidade nas propostas de tradução adotadas e, portanto, não há uma clara tendência de tradução das músicas uma vez que apenas um terço das canções são legendadas, o que inevitavelmente irá ocasionar perdas nas nuances e nas conotações veiculadas pelas músicas. Por último, quando contrastamos os nossos resultados com os apresentados em outras investigações sobre a tradução da obra do realizador para outras línguas e culturas, constatamos que também não existe uniformidade nos dados obtidos. Palavras chave: Cinema. Músicas. Legendagem. Normas. Almodóvar.
\end{abstract}

Abstract: Since the birth of cinema music has been an important part of movies. In Pedro Almodovar's work the soundtrack occupies a central place, not only speaking of the characters but also participating in the narratives. The final goal of this research is to confirm the existence of translation tendencies or norms in the specific case of the songs that integrate the films, based on the distinction established by Toury (1985) between preliminary norms and operational norms. We study a corpus composed by the last eight feature films of the Spanish director - from All about my mother (1999), which won the Oscar for the best foreign language film until the last film debuted in Portugal, Julieta (2016). We will see if inter-comprehension and linguistic and territorial proximity can influence the solutions adopted in subtitling. The research allows us to conclude that there is no homogeneity in the translation proposals adopted and, therefore, there is no clear trend to translate the songs since only a third of the songs are subtitled, which will inevitably cause losses in nuances and connotations transmitted through songs. Finally, when we contrast our results with those presented in other investigations about the translation of the director's films into other languages and cultures, we find that there is also no uniformity in the data obtained.

Keywords: Cinema. Music. Subtitling. Norms. Almodóvar.

Resumen: Desde el nacimiento del cine la música parte de las películas. En la obra de Pedro Almodóvar la banda sonora ocupa un lugar central, hablando de los personajes y participando en las narraciones. El objetivo final de esta investigación es verificar (o no) la existencia de tendencias o normas de traducción en el caso específico de las canciones que integran las películas, siguiendo la distinción establecida por Toury (1985)

SANCHIS, M. Dolores Lerma. Cinema, música e tradução: Pedro Almodóvar legendado em Portugal. Belas Infiéis, Brasília, v. 8, n. 4, p. 133-154, 2019. 
entre normas preliminares y normas operativas. Comenzamos con el estudio de un corpus compuesto por los últimos ocho largometrajes del director español, desde Todo sobre mi madre (1999), que ganó el Oscar a la mejor película en lengua extranjera hasta la última película que debutó en Portugal, Julieta (2016). Creemos que aspectos como la inter-comprensión y la proximidad lingüística y territorial pueden influir en las soluciones adoptadas por los traductores en el subtitulado. La investigación nos permite concluir que no hay homogeneidad en las propuestas de traducción adoptadas y, por lo tanto, no hay una tendencia clara de traducción de las canciones, ya que solo una tercera parte de las canciones están subtituladas, lo que inevitablemente causará pérdidas de matices y connotaciones vehiculadas por las canciones. Finalmente, cuando comparamos nuestros resultados con los presentados en otras investigaciones sobre la traducción del trabajo del director a otros idiomas y culturas, encontramos que tampoco hay uniformidad en los datos obtenidos.

Palabras clave: Cine. Músicas. Subtitulado. Normas. Almodóvar.

RECEBIDO EM: 17/04/2019

ACEITO EM: 10/08/2019

PUBLICADO EM: 10/2019 


\section{Introdução}

tualmente, os estudos em Tradução Audiovisual (TAV) atravessam um momento
de forte vitalidade. Contudo, estamos cientes da carência de pesquisas em TAV
aplicadas à combinação das línguas e culturas portuguesa e espanhola, tanto desde a hispanofonia como desde a lusofonia. Neste âmbito, um olhar sobre a bibliografia publicada aponta para a necessidade de expandir os territórios de investigação para outros pares de línguas e culturas, para além do inglês. Não pretendermos questionar a centralidade da língua inglesa, com o seu enorme peso na indústria audiovisual e no espaço cultural e econômico ocidental. Pelo contrário, parece-nos que a globalização deverá promover o multiculturalismo característico das sociedades contemporâneas. Em geral, na maioria dos estudos aplicados em TAV, a investigação feita em Portugal e em Espanha foca textos que incluem a língua inglesa como língua-cultura de origem, pelo que nos parece pertinente contribuir com um estudo que amplie o leque de culturas estudadas.

No presente trabalho percorremos o seguinte trajeto: em primeiro lugar realizamos uma introdução ao enquadramento teórico onde justificamos a escolha da combinação linguística e apresentamos o objetivo da pesquisa, centrado em procurar as tendências de tradução nas músicas do corpus selecionado, a partir do constructo teórico da teoria das normas de Toury (1985). A seguir, expomos as perspetivas teóricas que sobre a temática abordada teceram os especialistas em Tradução Audiovisual (TAV). A pesquisa continua com a análise dos casos encontrados no corpus sendo complementada com a comparação com os resultados obtidos noutras pesquisas focadas na tradução da filmografia do mesmo realizador para outras línguas e culturas. Finalizamos o estudo com a enumeração das conclusões mais significativas.

\section{Enquadramento teórico}

Uma vez que o objetivo final desta pesquisa é comprovar a existência de tendências ou normas de tradução para as músicas que integram os filmes do corpus selecionado, seguimos a teoria das normas (TOURY, 1995). O autor vê as normas como instruções de atuação para os tradutores, distinguindo três tipos que operam em diferentes fases do processo de tradução: as normas iniciais, as preliminares e as operacionais. Neste trabalho centrar-nos-emos nas duas últimas. As normas preliminares (preliminar norms) se referem tanto à existência de uma política de tradução concreta. Esta política comporta a presença de fatores que regulam a escolha de um determinado texto ou tipo textual de uma determinada cultura, num dado 
momento. Por sua vez, as normas operacionais (operational norms) comandam as decisões tomadas durante o ato da tradução e orientam sobre o que permanece invariável e o que muda no texto de chegada. Dentro das normas operacionais, Toury (1995) identifica dois grupos: as matriciais que governam a existência do material previsto na língua de chegada para substituir o material correspondente na língua original; e as linguístico-textuais que regem a seleção do material do repertório próprio que irá formular o texto traduzido e ocupará o lugar do material linguístico e textual do texto original, isto é, guiam as opções linguísticas e estilísticas e afetam ao nível microtextual.

Os textos audiovisuais são um constructo semiótico de carácter híbrido, do ponto de vista textual e de gênero, atendendo à variedade de conteúdos e, sobretudo, aos diferentes códigos de significação que operam sincronicamente na produção de sentido (CHAUME, 2003, 2004). Assim, um filme não é um texto unívoco e plano na medida em que

[...] se compone de una serie de signos codificados y articulados según unas reglas sintácticas. Su tipología, su modo de organización y el significado que todo ello comporta, dan como resultado en un entramado semántico que el espectador deconstruye para interpretar el sentido del texto (CHAUME, 2004, p. 19).

Chaume (2004) adota a proposta de Carmona (1996) a propósito da existência de quatro macrocódigos que interagem nos textos audiovisuais: os tecnológicos, os visuais, os sintáticos ou de montagem e os sonoros. Dentro dos sonoros, são especialmente interessantes para o tradutor o linguístico, o paralinguístico, o de colocação do som, o musical e o código dos efeitos especiais.

A perspetiva com que é encarada a tradução das músicas nos filmes varia consoante o tipo do texto, será diferente num filme do gênero musical, onde naturalmente todas as músicas serão traduzidas, ou noutro onde apenas são intercaladas algumas canções. Como ponto de partida, e para evitar que o espectador se desconcentre, o critério de uniformidade e homogeneidade das soluções adotadas ao longo do filme deve prevalecer (BARTOLL, 2012; DÍAZ-CINTAS, 2003). Tradicionalmente, é consensual a opção por traduzir as letras sempre que estas "[...] have a bearing on the story or throw light on the content of the film" (IVARSSON; CARROLL, 1998, p. 120). Mas a reiterada ideia sobre o peso argumental das canções não é pacífica, uma vez que a sua relevância acaba por ser decidida pelo iniciador da tradução ou pelo tradutor, sendo condicionada seja pela encomenda de tradução, seja pelo facto de o guião de pós-produção conter ou não as letras dos temas interpretados. 
À partida, as obras de Almodóvar não deveriam apresentar dúvidas quanto ao destaque das músicas nos seus filmes, atendendo às palavras do cineasta na entrevista concedida a Frédéric Strauss (1995): “la música la elijo directamente con el corazón. Pongo estas canciones porque me gustan y también porque hablan de los personajes, están destiladas o filtradas por las necesidades de las películas." (STRAUSS, 1995, p. 126), pelo que deduzimos que nunca são gratuitas. Aliás, muitos dos temas incluídos nos filmes fazem parte da bagagem musical dos recetores da cultura de origem, pois pertencem ao repertório musical popular, além de ser interpretados por nomes notáveis de alcance internacional. Sendo assim, é provável que determinadas músicas evoquem emoções que dificilmente se irão reproduzir no público da cultura de chegada, o que não invalida a importância da tradução das letras das canções, pois além da emoção comportam informação referencial.

Igareda (2012), relativamente à diversidade de funções da música nos filmes, resume os contributos de outros autores no seguinte inventário:

- to create a broad level of structural and stylistic unity, or musical "concept";

- to create a sense of period, location, or cultural background;

- to provoke a sense of epic grandeur;

- to accompany and support action, such as providing a musical emphasis to sound effects;

- to provide pacing, both in individual scenes and on a broader structural level;

- to underscore dialogue;

- to link scenes;

- to emphasise or highlight movement, mood or humour;

- to de-emphasise or contrast visual movement, mood or humour;

- to show changes in moods and feelings, and accumulate emotional states;

- to pre-empt the mood of an upcoming scene;

- to play the thoughts of characters, rather than the actions;

- to play an additional character, such as a ghost, or something imagined;

- to provide a subtext: to inform the audience of events or circumstances of which the movie characters are unaware;

- to flesh out the aural environment, contributing to a sense of spatial reality (diegetic music only);

- to provide another level of rhythm to the rhythm of the editors cut;

- and to follow the movement of the camera (IGAREDA, 2012, p. 238-239)

$\mathrm{Na}$ ótica da TAV e da legendagem, há algumas considerações a ponderar na abordagem desta problemática. Em primeiro lugar, a prioridade dos diálogos ou de outras vozes provenientes de discursos, diálogos, programas de televisão, genéricos, etc. sobre as canções. Em segundo lugar, as convenções ortotipográficas que estabelecem o uso do itálico para distinguir as legendas das músicas do resto do texto (BARTOLL, 2012; IVARSSON; CARROLL, 1998; CHAUME, 2004). Em Portugal, esta convenção coexiste com a de alinhar 
o texto à esquerda, utilizando o mesmo tipo de letra que nas restantes legendas. Sem esquecer que, em comparação com as legendas dos diálogos, é permitida uma maior flexibilidade no tempo em que se introduz cada legenda para acompanhar o ritmo e o tempo das letras. Assim, por vezes, as legendas permanecem no ecrã durante mais tempo do habitual para respeitar a sincronia; outras vezes, a estrutura da música pode exigir a alteração da sintaxe das legendas para não disponibilizar a informação demasiado cedo (DÍAZ-CINTAS; REMAEL, 2007). As convenções seguidas por algumas empresas de tradução aplicam o modelo da poesia, de modo que cada linha começa com letra maiúscula e não são colocados sinais de pontuação. Contudo, é recomendado o uso das regras de pontuação utilizadas no resto das legendas para facilitar a leitura (DÍAZ-CINTAS; REMAEL, 2007). Concordamos absolutamente com esta apreciação, uma vez que o público está habituado a ler legendas seguindo as regras de pontuação e, se forem suprimidas podem causar sem sentidos, ambiguidades ou outros problemas que interfiram na compreensão. As canções legendadas no corpus seguem esta norma, conservam os sinais de pontuação e procuram uma sincronização, tão próxima quanto possível, entre aquilo que se ouve e aquilo que se lê.

\section{Aplicação prática}

\section{1 análise qualitativa do corpus e discussão dos resultados}

As obras cinematográficas selecionadas para o estudo pertencem ao espaço temporal delimitado pela longa-metragem Todo sobre mi madre / Tudo sobre a minha mãe (1999), que consagrou internacionalmente Pedro Almodóvar com a obtenção do Óscar para o melhor filme em língua estrangeira, até a última estreada quando iniciamos a investigação, Julieta / Julieta (2016). Entre os dois limites: Hable con ella / Fala com ela (2002), La mala educación / Má educação (2004), Volver Volver / Voltar (2006), Los abrazos rotos / Abraços desfeitos (2009), La piel que habito / A pele onde eu vivo (2011), Los amantes pasajeros / Os amantes passageiros (2013). Todas as fitas compartilham gênero, entre a comédia e o melodrama, e foram estreadas em salas de cinema portuguesas e comercializadas em DVD.

Almodóvar autodefine-se como um melómano e o seu cinema corrobora-o. Esta ideia, reiterada na bibliografia sobre o realizador, leva-nos a observar o tratamento das canções na tradução. Ao abordar este campo, interessa confirmar se existe uma norma na transposição das músicas dos filmes selecionados. Importa dizer que apenas mencionaremos as canções interpretadas nos filmes cuja letra seja suscetível de ser traduzida, não aludiremos às músicas sem letra, habitualmente concebidas para fazer parte da trilha sonora dos filmes. A partir de 
Todo sobre mi madre todos os títulos do realizador são acompanhados de uma trilha sonora original do compositor Alberto Iglesias.

A análise do corpus escolhido para o estudo mostra que, do ponto de vista da tradução espanhol-português e no que respeita à legendagem das músicas interpretadas nos filmes, prevalecem as práticas a seguir descritas:

I. Sempre que as músicas são cantadas numa língua diferente à dos diálogos é habitual que não se legendem (DÍAZ-CINTAS, 2003). No corpus, esta situação ocorre em três momentos:

i. $\quad$ Em Todo sobre mi madre (1999), na interpretação do senegalês Ismaël Lô da canção Tajabone - cantada em wolof, a língua oficial do Senegal - que ambienta a chegada a Barcelona de Manuela (Cecilia Roth). A imagem acompanha a sua vinda num comboio que ao atravessar um túnel permite deixar o passado para atrás. Em simultâneo, a voz de Ismaël Lô envolve a imagem noturna da cidade, no Campo onde os transexuais se prostituem e Manuela procura Agrado (Antonia San Juan). Tajabone fala da festa da celebração do fim do Ramadão, onde as pessoas trocam comida, os rapazes se vestem de raparigas e vice-versa. $\mathrm{O}$ som e o ritmo pausado e melancólico transferem o tom ao momento do filme. Esta passagem cumpre a função que Carmona (1996) atribui a algumas canções: indicar a separação ou a continuidade entre sequências, contribuindo para dar coesão e segmentar o texto, como se de um sinal de pontuação se tratasse.

ii. Em Los amantes pasajeros (2013), numa cena, em tom de comédia, em que os comissários de bordo executam uma coreografia com a canção I'm So Excited interpretada por The Pointer Sisters. Esta poderia ser considerada uma das circunstâncias em que a tradução é prescindível, mas isto não retira centralidade à música, reforçada pelo facto de o filme ter sido comercializado em inglês com o mesmo título.

iii. A terceira ocorrência pertence a La mala educación (2004). O tema italiano Cuore Matto interpretado por Little Toni, ouve-se no rádio do carro numa cena entre dos dois velhos amigos, Juan (Gael García Bernal) e Enrique Goded (Fele Martínez). A presença da música é marcante, mas não tanto o significado da letra que fala do coração louco que ainda ama e perdoa, quiçá por este motivo não é traduzida. Além disso, no início sobrepõe-se a conversa entre as duas personagens e a música, mas depois ouve-se apenas a canção. É habitual nestes 
casos que as legendas priorizem o conteúdo do diálogo (DÍAZ-CINTAS, 2003). Mas também seria uma possibilidade a alternância de fragmentos legendados com outros sem legendar.

II. Observamos falta de homogeneidade nas soluções de tradução das músicas interpretadas na língua original do filme, ouvidas isoladamente e sem sobreposição com os diálogos. Não percebemos o motivo pelo qual não foram traduzidas as letras de três canções interpretadas em espanhol. São os seguintes casos:

i. A voz sussurrante de Caetano Veloso numa contida interpretação da canção mexicana Cucurrucucú paloma de Tomás Méndez Sosa, num emotivo momento em Hable con ella (2002). Na cena, ambientada numa atmosfera requintada e poética, a música acompanha uma conversa entre a toureira e o jornalista em que paira o possível começo de uma relação. Poderiam existir, portanto, fundamentos a favor da sua tradução, mas também poder-se-ia argumentar que o ritmo pausado da interpretação não é um grande impedimento para que o público-alvo acompanhe a letra.

140 ii. A singela interpretação da voz acompanhada ao piano do tema Se me hizo fácil, da maiorquina Concha Buika, em La piel que habito (2011). Trata-se da adaptação de uma rancheira, uma canção de amor, desamor e esquecimento, tão típicas do gosto melodramático do realizador. A cena decorre num ambiente festivo, durante a celebração de um casamento ao que assistem o Dr. Legard (Antonio Banderas) e a filha Norma (Blanca Suárez). A interpretação precede a dramática cena da violação de Norma que representará um ponto de viragem na vida das duas personagens e do enredo do filme.

iii. No mesmo filme, La piel que habito (2011), nas vozes alternadas de Concha Buika e Norma (Ana Mena) escuta-se, em espanhol e português o tema Pelo amor de amar / Necesito amor, resgatado do repertório da cantora brasileira Ellen de Lima. As duas vezes em que o tema se ouve no filme coincidem com momentos de forte intensidade dramática e argumental. A primeira precipita a morte da mãe de Norma; a segunda, a violação. O tema original em português legitima a não tradução.

Possivelmente outros critérios poderão ser tidos em conta nestas circunstâncias. DíazCintas (2003) cita Ivarsson (1992) que, em contextos semelhantes, aduz exigências de produtores e distribuidores. Do nosso ponto de vista, a relativa facilidade de compreensão do público português não deveria ser interpretada como justificação para a não tradução. 
Consideramos que as músicas em espanhol ou noutra língua estrangeira deveriam ser legendadas, sempre que existam condições para o fazer.

III. Finalmente, há quatro temas sem traduzir para os quais inferimos diferentes razões:

i. Em Hable con ella (2002), a cantora brasileira Elis Regina interpreta Por toda a minha vida, de Tom Jobim e Vinicius de Moraes. A música acompanha a atuação da toureira, e enquanto soa ouvimos uma conversa explicando que a tourada é dedicada ao antigo amor da toureira, o Niño de Valencia, uma história de amor não esquecida. A música é cantada em português, pelo que a legendagem é desnecessária.

ii. A primeira cena de Volver (2006) é filmada no cemitério, nela as mulheres conversam enquanto escutamos o tema Las espigadoras, do maestro Guerrero, interpretado por Conchita Penadés. Há uma rápida sobreposição dos diálogos das personagens com a música que enceta o filme, e a não tradução da letra em nada afeta a compreensão da cena ou do filme.

iii. O cantaor de flamenco Miguel Poveda interpreta o tema A ciegas, em Los abrazos rotos (2009). A música não é legendada, pois coincide com a indicação dos créditos.

iv. Nos créditos finais de Julieta (2016), a mexicana Chavela Vargas canta Si no te vas. Também é habitual neste contexto prescindir da legendagem da música. De facto, por vezes as distribuidoras, especialmente as norte-americanas, exigem que o tema musical não seja legendado para não dificultar a leitura dos créditos (IVARSSON, 1992).

$\mathrm{V}$.

A música de um filme está em harmonia com a imagem e os diálogos, não é um elemento gratuito, a sua finalidade é provocar emoções, antecipar cenas, conferir um sabor global à fita e às situações concretas que acompanha. São quinze os temas musicais destacados no corpus, dos quais apenas quatro se legendam, apesar de que todos se localizem em momentos comovedores, alimentando a carga dramática do filme. Sobre os quatro temas legendados, a seguir, tecemos algumas considerações:

1. Em La mala educación (2004), o travesti Zahara (Gael García Bernal) interpreta em playback um tema popular, Quizás, quizás, quizás, interpretado pela voz de Sara Montiel e ao mesmo tempo que o interpreta descobre entre o público Enrique, um antigo amor. Na versão legendada o ritmo e a rima são conservados. Uma vez que as línguas o permitem, é feita uma 
tradução muito literal e próxima do TO, o que favorece a sincronização das vozes com as legendas que permanecem no ecrã o tempo suficiente para serem lidas.

\section{Quizás, quizás, quizás}

Siempre que te pregunto

que cuándo, cómo y dónde,

tú siempre me respondes:

Quizás, quizás, quizás.

Ya sí pasan los días.

Y yo desesperando.

Y tú, tú contestando:

Quizás, quizás, quizás.

2. Em Volver (2006), a protagonista canta em playback o tema Volver. Trata-se de uma versão por bulerías de um conhecido tango de Carlos Gardel e Alfredo Le Pera interpretado por Estrella Morente. A música surge no decurso de uma festa organizada para celebrar o fim dos trabalhos de filmagem de um grupo que contratara os serviços do restaurante de Raimunda (Penélope Cruz). Esta ouve os acordes de uma canção que a mãe lhe ensinara sendo miúda, e canta para o grupo e para a filha que nunca a ouvira cantar. A mãe, Irene (Carmen Maura), escuta escondida a música. Deste modo, os fios narrativos do passado e do presente convergem. A partir desse momento passam a ser abordados novos aspetos sobre o passado das personagens. Em consequência, na medida em que os textos musicais 
acompanham argumentalmente o texto fílmico, estes podem ser considerados como metatextos.

Estamos perante uma tradução bastante literal, a intercompreensão e a proximidade linguística explicam a solução adotada. Assim, o espectador vai se sentir mais confortável e vai poder concentrar-se na narrativa ao não encontrar na tradução elementos que possam distraí-lo. As legendas respeitam o ritmo e preservam algumas das rimas do tema original.

\section{$\underline{\text { Volver }}$}

Tengo miedo del encuentro

Con el pasado que vuelve

A enfrentarse con mi vida

Tengo miedo de la noche

que, poblada de recuerdos,

encadena mi soñar.

Pero el viajero que huye

tarde o temprano detiene su andar.

Y aunque el olvido,

que todo lo destruye,

haya matado mi vieja ilusión,

guardo escondida

una esperanza humilde

que es toda la fortuna

de mi corazón.

Volver

con la frente marchita,

las nieves del tiempo

platearon mi sien.

Sentir

que es un soplo la vida,

que veinte años no es nada,

que febril la mirada,

errante en las sombras
- Tenho medo do encontro

- Com o passado

Que volta

- Para confrontar a minha vida

- Tenho medo da noite

- Que, povoada de recordações,

- Encadeia o meu sonhar

- Mas o fugaz viajante

- Mais tarde ou mais cedo

Detém o seu andar

- E apesar do esquecimento

Que tudo destrói

-Ter morto a minha velha ilusão

- Ainda guardo cá dentro

Uma humilde esperança

- Que é toda a fortuna

Do meu coração

- Voltar

- Com o rosto sulcado

As neves do tempo

- Pratearam as minhas fontes

Sentir

- Que a vida é um instante

- Que vinte anos não são nada 
te busca y te nombra.

Vivir

con el alma aferrada

a un dulce recuerdo

que lloro otra vez.
- Que o olhar febril

Errante nas sombras

- Te procura e te nomeia

Viver

- Com a alma apegada

A uma doce recordação

- Pela qual choro outra vez

3. Em La mala educación (2004), Ignacio canta em playback o tema Moon River, de Henry Mancini e Johnny Mercer. A pureza da voz infantil de Pedro José Sánchez acompanha uma cena perturbadora em que os alunos com melhores notas são premiados com um dia no campo na companhia do padre Manolo (Daniel Giménez Cacho), o professor de literatura. A imagem mostra Ignacio a interpretar o tema para o padre Manolo. No fim foge correndo perante o assédio do padre. A tradução segue de perto o original e introduz algumas alterações sintáticas para manter o ritmo.

\section{Moon River}

Moon River,

no te olvidaré.

Yo no me dejaré llevar

por el agua,

agua turbia

del río y de la luna

que suena al pasar.

Río y luna,

dime dónde está,

mi Dios, el bien y el mal,

decid.

Yo quiero saber

qué se esconde

en la oscuridad

y tú lo encontrarás.
- Moon River

- Nunca te esquecerei

- Não mais

- Me deixarei levar

- Por essa

- Água

- Água

- Turva

- Do rio

E da lua

- Que soa ao passar

- Rio e lua

- Digam-me onde está

- O meu Deus

- O Bem e o Mal 
- Digam-me

- Eu quero

- Saber

- O que se esconde

- Na obscuridade

- E tu hás-de encontrá-lo

4. Em La mala educación (2004), numa cena no refeitório diante de todos os padres, Ignacio (Nacho Pérez) interpreta uma versão de, Torna a surriento (agora intitulada Jardineiro), o tema preferido do padre Manolo, para comemorar o seu aniversário. A importância deste momento na trama é indiscutível, dado que nas entrelinhas da canção é possível compreender a relação das duas personagens. A emotividade da letra articula-se com a perversidade do desejo expresso no olhar do aniversariante. O padre Manolo é o autor da nova letra da canção que ao ouvir a voz do jovem rapaz se mostra vivamente emocionado. A tradução conserva o tom.

\section{$\underline{\text { Jardinero }}$}

Jardinero, jardinero.

Noche y día entre tus flores, encendiendo sus colores con la llama de tu amor. Vas poniendo en cada cáliz la sonrisa de tu anhelo, con los ojos en el cielo donde tienes tu ilusión. Y tus flores, jardinero, de corolas encendidas que al unirse agradecidas te embalsaman con su olor.

Sigue tu labor cultivando las flores
- Jardineiro

- Noite e dia

Entre as tuas flores

- Incendiando as suas cores

- Com a chama

Do teu amor

- Vais pondo em cada cálice

- O sorriso do teu desejo

- De olhos postos no céu

- Onde tens

As tuas ilusões

$-\mathrm{E}$ as tuas flores

Jardineiro

- De corolas incendiadas 
que a tus amores

confió el Señor.
- Que ao unir-se

Agradecidas

- Te embalsamam

Com seu odor

- Continua o teu labor

- Cultivando as flores

- Que ao teu amor

- Confiou

O Senhor

As canções fazem parte do código musical do texto audiovisual junto à trilha sonora. Se bem que mostremos algumas disparidades no tratamento da legendagem nos distintos textos, na maior parte dos temas traduzidos existem uma série de pontos comuns que vão ao encontro das reflexões de Chaume (2004, p. 203) sobre este aspeto:

la subtitulación de canciones debe respetar ciertos ritmos musicales del original, de modo que se haga coincidir el subtítulo con los versos pronunciados en cada momento, y de manera que se respeten también las pausas musicales de cada canción. Sin embargo, no se exige en ningún caso la rima del texto origen, ni los ritmos de intensidad, cantidad y tono que pudiera presentar el texto origen, es decir, se requiere simplemente una traducción del sentido (...) a no ser que el traductor posea también una buena formación en traducción literaria y quiera recrearse dando rienda suelta a su creatividad.

Da ótica da distinção entre a música expressiva - quando a trilha sonora exprime um sentimento ou um estado emocional - e a música estrutural - quando não exprime nada, e simplesmente está como música de fundo - (OLARTE, 2002), os temas escolhidos pelo realizador no corpus integrariam o primeiro tipo. Não obstante, esta distinção pode ser entendida apenas como uma questão de grau.

A música nos filmes tem o poder de despertar para outras leituras relacionadas com sentidos e interpretações sociológicas ou históricas das obras em que se inserem. Rox (2008) refere que a música Tajabone, além da relevância temática e diegética, “[...] provides meaning for the development of the action: "Tajabone" is a song for a Muslim celebration about the love of children; so it fits perfectly in a film about motherhood" (ALLINSON, 2001: 198; cit. por ROX, 2008, p. 118). A ideia de continuidade, refletida na imagem da viagem de comboio que leva a protagonista até Barcelona, "[...] introduces a significant African cultural referent that complements Almodóvar's cinematic vision of Barcelona as a global city" 
(AMAGO, 2007, p. 14 apud ROX, 2008, p. 118). A autora relaciona ainda esta ideia com o afluxo de emigração na mesma cidade.

O quadro seguinte resume as canções do corpus indicando o filme a que pertencem, o intérprete, e se foram ou não traduzidas na legendagem das fitas exibidas nos ecrãs dos cinemas lusos. Como se constata, dos quinze temas apenas quatro foram legendados.

Quadro 1 - Canções do corpus

\begin{tabular}{|c|c|c|}
\hline Filme & Música/ voz & Tradução \\
\hline Todo sobre mi madre & Tajabone - Ismaël Lô & Não \\
\hline \multirow[t]{2}{*}{ Hable con ella } & Por toda a minha vida - Elis Regina & Não \\
\hline & Сиситrисиси́ paloma - Caetano Veloso & Não \\
\hline \multirow[t]{5}{*}{ La mala educación } & Moon River - Pedro José Sánchez & Sim \\
\hline & Torna a surriento (Jardinero) & Sim \\
\hline & Maniquí parisien - Sara Montiel & Não \\
\hline & Quizás, quizás, quizás - Sara Montiel & Sim \\
\hline & Cuore Matto - Little Toni & Não \\
\hline \multirow[t]{2}{*}{ Volver } & Las espigadoras & Não \\
\hline & Volver-Estrella Morente & $\operatorname{Sim}$ \\
\hline Los abrazos rotos & A ciegas - Miguel Poveda & Não \\
\hline \multirow[t]{2}{*}{ La piel que habito } & Se me hizo fácil-Buika & Não \\
\hline & $\begin{array}{l}\text { Pelo amor de amar/Necesito amor - } \\
\text { Buika; Norma }\end{array}$ & Não \\
\hline Los amantes pasajeros & I'm So Excited - The Pointer Sisters & Não \\
\hline Julieta & Si no te vas - Chavela Vargas & Não \\
\hline
\end{tabular}

\section{A tradução das músicas dos filmes de Almodóvar noutras investigações}

[...] el auteur transnacional por excelencia dentro del espacio europeo; [...]. En su conjunto, la cinematografía de este director presenta unas características recurrentes, lo que podríamos llamar estilemas, que la hacen reconocible en naciones tan dispares como Japón y Estados Unidos, que consideran su obra como muy representativa de su país de origen por su incorporación de elementos hipotéticamente arquetípicos pese a que, por otra parte, su excelente dominio de las convenciones canónicas de la cinematografía universal contribuye en gran medida a facilitar su traslación a muy diversos contextos culturales.

(SANDERSON, 2011)

SANCHIS, M. Dolores Lerma. Cinema, música e tradução: Pedro Almodóvar legendado em Portugal. Belas Infiéis, Brasília, v. 8, n. 4, p. 133-154, 2019. 
Cotejar outras pesquisas, que partem de corpora análogos e com características afins, permite apreciar de que modo as culturas defrontam e resolvem dificuldades de tradução semelhantes. Através das investigações, perspetivadas desde diferentes línguas e culturas, os seus autores mostram como os tradutores se enfrentam às traduções. Todas elas trespassam as barreiras linguísticas e culturais, algumas com entraves acrescidos ao fazê-lo com alfabetos diferentes ou mediante o recurso a traduções mediadas, inclusive por meio de listas de diálogos em inglês. Todas as realidades afetam o resultado final.

Na nossa pesquisa encontramos treze estudos da obra de Almodóvar na perspetiva da TAV, o que confirma o interesse despertado entre os investigadores numa análise deste género. Os estudos localizados estão disseminados por diversos centros de investigação e se apresentam em distintos formatos: artigos de livros e revistas, teses de mestrado, trabalhos de investigação de fim de curso e teses de doutoramento. Por ordem cronológica, os títulos consultados foram os seguintes:

1. Ana Moreno, La traducción de elementos culturales en el texto audiovisual. La obra de Pedro Almodóvar en alemán, francés e inglés, 2005.

2. María Roussou, La subtitulación de tres filmes de Almodóvar al griego: Estudio descriptivo, 2005.

3. Zsuzsanna Lakatos, Kulturális reáliák egy spanyol film magyarra és portugálra fordított változatában, (Realia cultural na versão para português e húngaro de um filme espanhol), 2008.

4. María Rox Barasoain, The films of Pedro Almodóvar: translation and reception in the United States, 2008.

5. María Lomeña Galiano, Variación lingüística y traducción para el doblaje: mujeres al borde de un ataque de nervios, 2009.

6. Signe Kok Sørensen \& Lea Beliaeva Bander, El subtitulado no una cosa de coser y cantar. Un análisis de los subtítulos daneses de la película Volver de Pedro Almodóvar, 2010.

7. Juan Tomás Matarranz Araque e María Mar Soliño Pazó, Traducción y doblaje: el cine de Almodóvar en alemán e inglés, 2011.

8. John Douglas Sanderson, Imágenes en palabras. La audiodescripción como generadora de estrategias alternativas de traducción, 2011. 
9. Leticia Santamaría Ciordia, Almodóvar po polsku. La imagen de Almodóvar en Polonia y sus consecuencias sobre la traducción de su cine, 2012.

10. Yi-Chen Wang, Los marcadores conversacionales en el subtitulado del español al chino: análisis de "La mala educación" y "Volver" de Pedro Almodóvar, 2013.

11. Antonio Terrón Barroso, La traducción de estereotipos, variación lingüística y nombres propios en "Todo sobre mi madre” de Pedro Almodóvar (español-inglés y español-francés), 2015.

12. María Teresa Amido Lozano, La traducción de referencias culturales para el doblaje. Un estudio sobre la recepción del cine de almodóvar en Alemania, 2015.

13. Nirachon kerdkidsadanon, La traducción para el subtitulado al tailandés del cine de Pedro Almodóvar, 2015.

De facto, são poucos os autores que referem o problema das traduções das letras dos temas musicais; entre todos os trabalhos apenas Roussou (2005), Moreno (2005), Sørensen e Bander (2010) e Santamaría Ciordia (2012) abordam esta problemática.

Roussou (2005), na transposição para grego das músicas de Carne trémula (1997), Todo sobre mi madre (1999) e Hable con ella (2002), indica que são traduzidos três dos quatro temas, admitindo que um corpus tão reduzido não permite definir uma norma. Mas é interessante a sua reflexão sobre a necessidade de critérios objetivos que ajudem a discernir se uma música tem ou não relação direta com a trama do filme. Isto porque cada recetor de acordo com a sua experiência, sensibilidade, gosto ou conhecimentos, pode fazer a sua interpretação particular.

Os fatores externos, relacionados com a encomenda de tradução e a documentação que o tradutor recebe, têm um peso considerável. Moreno (2005) analisa a tradução para francês, alemão e inglês britânico dos filmes Mujeres al borde de un ataque de nervios (1988), La flor de mi secreto (1995), Todo sobre mi madre (1999), Hable con ella (2002) e La mala educación (2004). A autora refere que os guiões de pós-produção consultados, facultados pela produtora $\mathrm{El}$ Deseo, não contêm as letras. Neste estudo, a norma é a não tradução nas dublagens para francês, alemão e inglês; quando se trata de legendar, os textos de chegada (TC) apresentam as traduções de temas com função diegética, sendo habitualmente muito literais.

$\mathrm{Na}$ legendagem de Volver (2006) para dinamarquês, Sørensen \& Bander (2010) justificam a não tradução do tema Las espigadoras pela sobreposição com os créditos e os 
diálogos iniciais do filme, uma vez que consideram a música relevante, pois exprime o sentimento de comunidade das mulheres da terra e a ideia da dureza da tarefa de cuidar do cemitério. O tema Volver é traduzido, mas o tradutor opta por conservar o conteúdo semântico em detrimento do ritmo e a rima, ainda que por vezes se percam matizes.

A publicação de Santamaría Ciordia (2012) recolhe um total de 26 músicas em 12 filmes, das quais 12 são traduzidas para polaco. A autora valora individualmente se se trata de uma perda mais ou menos significativa e indica que na legendagem para polaco nunca se traduzem as músicas secundárias, embora não assinale os critérios que levam a tal consideração.

Com frequência os ensaios sobre a filmografia de Almodóvar, fora do enfoque da tradução, realçam o papel da música na sua filmografia. Em geral todas as músicas têm uma razão de ser, não sendo incorporadas gratuitamente. Do ponto de vista da tradução, a relevância diegética da mensagem transmitida nas letras e a literalidade das traduções são os factos que se destacam no corpus.

\section{Considerações finais}

As canções nos filmes do cineasta costumam cumprir uma função no contexto em que surgem, relacionando-se com outros elementos como a linguagem verbal, a imagem, os estados anímicos, etc. Tal como Almodóvar afirma falam das personagens e respondem às necessidades da narrativa.

No corpus, das quinze músicas - interpretadas em wolof, português, inglês, espanhol e italiano - apenas um terço são legendadas. Tendo em conta a relevância que o próprio realizador atribui à música dos filmes, pensamos que a não tradução implica perder nuances e conotações. Certamente nem sempre era possível traduzir algumas das músicas, principalmente pela simultaneidade com os diálogos e noutras vezes não conseguimos perceber a ausência das legendas. A conclusão que retiramos é que há falta de homogeneidade nas soluções, pelo que não existe uma clara tendência quanto à legendagem das músicas interpretadas nos filmes independentemente do seu papel, relevância, etc.

Sobre este aspeto, nas restantes investigações os dados retirados não apresentam uniformidade de resultados, apenas destaca a tradução para polaco pelo número de músicas traduzidas.

As dinâmicas comerciais, linguísticas e culturais encontram um ponto de intersecção na tradução. Notamos uma menor valorização no par de línguas portuguesa e espanhola por 
causa da proximidade estrutural e lexical. Num plano pragmático, para o falante de uma delas que está aprendendo a outra, a proximidade pode ser percebida como um elemento motivador porque na sua aprendizagem poderá beneficiar dos conhecimentos e habilidades que as duas línguas partilham para atingir mais rapidamente uma competência maior. Nessa medida, esta combinação, adicionada ao domínio de outra(s), tem um excecional potencial (DIAZ FOUCES, 2012).

$\mathrm{Na}$ combinação linguístico-cultural abordada, a distância cultural é mitigada pela proximidade física e a geografia peninsular. Neste sentido, é espectável que a cercania física e cultural existente, unida ao crescente e frequente fluxo de pessoas que atravessam a fronteira para férias, estudo ou trabalho, poderá tornar alguns elementos culturais reconhecíveis. Ou seja, a contiguidade poderá fazer com que o público português possa (re)conhecer ou compartilhar mais referentes culturais na filmografia de Almodóvar do que o fariam outras audiências geograficamente distantes.

Potencialmente aspetos como a proximidade entre os sistemas linguísticos e culturais envolvidos, as estreitas relações entre Portugal e Espanha em âmbitos diversos, assim como alguma facilidade de compreensão da LO por parte do público recetor fazem com que as traduções das legendas fiquem próximas do original. Porém, a perspetiva tanto de investigadores como de espectadores e observadores atentos leva-nos a admitir que a tendência estrangerizante é também observada nas legendagens portuguesas resultantes de outras combinações linguísticas e outros géneros audiovisuais, pelo que o hábito e a tradição são elementos a considerar.

Uma análise deste género ajuda a compreender o que o público português espera de uma legendagem em termos de permissibilidade, abertura e conhecimento da cultura vizinha. Do ponto de vista da didática da TAV achamos que os resultados obtidos poderão ser orientativos, tanto em contexto de formação quanto no profissional, já que estamos perante uma questão problemática quer para tradutores, quer para estudantes.

Por último, verificamos que não existe uma política de tradução planificada, uma vez que não há sistematicidade nos responsáveis por legendar os filmes. Todavia, há regularidade quanto à empresa de tradução, CRISTBET Traduções e Legendagens Lda., bem como à tradutora dos últimos filmes. Esta circunstância chama a atenção por quanto Almodóvar é um nome relevante na indústria do cinema que, por seu turno, ocupa um lugar central nas indústrias culturais. Podemos fundamentar esta situação pelo facto de a nossa pesquisa se focar numa combinação linguística considerada periférica, quanto mais não seja do ponto de 
vista da tradução audiovisual. Este facto contrasta com o que acontece dentro do sistema literário, principalmente nas traduções de autores portugueses canónicos para a língua espanhola, onde se observam modelos de uma política de tradução planificada. É o que acontece com as traduções da obra de José Saramago e de António Lobo Antunes, por exemplo.

\section{REFERÊNCIAS}

ALLINSON, Mark. A Spanish Labyrinth: The Films of Pedro Almodóvar. London \& New York: I.B. Tauris, 2001.

AMAGO, Samuel. Todo sobre Barcelona: Refiguring Spanish Identities in Recent European Cinema. HISPANIC RESEARCH JOURNAL 8.1, 2007, p.11-25.

BARTOLL, Eduard. La subtitulació. Aspectes teòrics i pràctics. Vic: Eumo, 2012.

CARMONA, Ramon. Cómo se comenta un texto fílmico. Madrid: Cátedra, 1996.

CHAUME, Frederic. Cine y traducción. Madrid: Cátedra, 2004.

152 CHAUME, Frederic. Doblatge i subtitulació per a la TV. Vic: Eumo Editorial, Universitat Pompeu Fabra, Universitat Autònoma de Barcelona, Universitat de Vic, Universitat Jaume I, 2003.

DIAZ FOUCES, Oscar. Algumas considerações sobre a combinação linguística portuguêsespanhol. In: DIAZ FOUCES, Oscar (Ed.), Olhares \& Miradas. Granada: Átrio, 2012, p. 119-135.

DÍAZ-CINTAS, Jorge. Teoría y práctica de la subtitulación: inglés/español. Barcelona: Ariel, 2003.

DÍAZ-CINTAS, Jorge; REMAEL, A. Audiovisual Translation: Subtitling. Manchester: St. Jerome, 2007.

IGAREDA, Paula. Lyrics against images: music and audioDescription. In: MonTI 4, p. 233254, 2012.

IVARSSON, Jan. Subtitling for the Media. A Handbook of an Art. Estocolmo: Transedit, 1992.

IVARSSON, Jan; CARROLL, Mary. Subtitling. Sweden: Simrishamn, 1998.

MORENO, Ana. La traducción de elementos culturales en el texto audiovisual. La obra de Pedro Almodóvar en alemán, francés e inglés. Universidad del País Vasco, Vizcaya, 2005. 
OLARTE, Matilde. La música incidental en el cine y el teatro. In: BANÚS, Enrique (Coord.). El legado musical del siglo XX. Pamplona: Ediciones Universidad de Navarra. EUNSA, 2002.

ROUSSOU, Maria. La subtitulación de tres filmes de Almodóvar al griego: Estudio descriptivo. Puentes 6, p. 61-68, 2005.

ROX, María. The films of Pedro Almodóvar: translation and reception in the United States. Tese de doutoramento, Universidad de León, León, Espanha, 2008. Disponível em: https://buleria.unileon.es/bitstream/handle/10612/1417/2008ROX\%20BARASOAIN,\%20MA R\%25CDA.pdf?sequence=1 Acesso em: abr. 2019.

SANDERSON; John D. Imágenes en palabras. La audiodescripción como generadora de estrategias alternativas de traducción. Puntoycoma. Boletín de los Traductores Españoles de las instituciones de la Unión Europea, n. 123. Disponível em:

http://ec.europa.eu/translation/bulletins/puntoycoma/123/pyc1238_es.htm. 2011 Acesso em: 7 out. 2019.

SANTAMARÍA CIORDIA, Letícia. Almodóvar po polsku. La imagen de Almodóvar en Polonia y sus consecuencias sobre la traducción de su cine. Lask: Oficyna Wydawnicza LEKSEM. Col. Rozumienie, Interpretacja, Przeklad, 2012.

SØRENSEN, Signe Kok; BANDER, Lea Beliaeva. EI subtitulado - no una cosa de coser y cantar Un análisis de los subtítulos daneses de la película Volver de Pedro Almodóvar.

Aarhus School of Business, Aarhus University, 2010. Disponível em:

http://pure.au.dk/portal/files/11665/EL_SUBTITULADO.pdf Acesso em: abril 2019.

STRAUSS, Frédéric. Pedro Almodóvar: un cine visceral. Madrid: Ediciones El País/Aguilar, 1995.

TOURY, Gideon. Descriptive Translation Studies and Beyond. Amsterdam: John Benjamins, 1995.

\section{REFERÊNCIAS DE FILMES}

A PELE onde eu vivo. Produção de: Augustin Almodóvar e Esther García. Realização de: Pedro Almodóvar. DVD. Portugal: Pris audiovisuais, 2012.

ABRAÇOS desfeitos. Produção de: Augustin Almodóvar e Esther García. Realização de: Pedro Almodóvar. DVD. Portugal: Prisvideo S.A., 2009.

FALA com ela. Produção de: Augustin Almodóvar e Michel Ruben. Realização de Pedro Almodóvar. DVD. Portugal: Prisvideo S.A., 2002.

JULIETA. Produção de: Augustin Almodóvar e Esther García. Realização de: Pedro Almodóvar. DVD. Portugal: Pris audiovisuais, 2016.

MÁ educação. Produção de: Augustin Almodóvar e Esther García. Realização de: Pedro Almodóvar. DVD. Portugal: Prisvideo S.A., 2004. 
OS AMANTES passageiros. Produção de: Augustin Almodóvar e Esther García. Realização de: Pedro Almodóvar. DVD. Portugal: Pris audiovisuais, 2013.

TUDO SOBRE a minha mãe. Produção de: Augustin Almodóvar e Michel Ruben.

Realização de Pedro Almodóvar. DVD. Portugal: Atalanta Filmes, 2001.

VOLVER Voltar. Produção de: Augustin Almodóvar e Esther García. Realização de: Pedro Almodóvar. DVD. Portugal: Prisvideo S.A., 2006.

\footnotetext{
* Maria Dolores Lerma SANCHIS - Doutora (2017) pela Universidade do Minho, Braga. Mestra (2007) pela Universidade do Minho, Braga. Graduada (1985) pela Universitat de València, Espanha. É professora do Departamento de Estudos Românicos na Universidade do Minho, Portugal. Minho, Portugal.

Currículo acadêmico: http://cehum.ilch.uminho.pt/researchers/9

ORCID: https://orcid.org/0000-0001-6704-5199

E-mail: llerma@ilch.uminho.pt
} 